\title{
Pengaruh Modul PBL Berorientasi Green Chemistry pada Materi Hidrolisis Garam terhadap Literasi Sains Siswa
}

\author{
*Suryati, Hendrawani, Nur Walidatun \\ Program Studi Pendidikan Kimia, FSTT Universitas Pendidikan Mandalika, J1. \\ Pemuda No 59A Mataram, 83125, Indonesia \\ *Corresponding Author Email: suryati@ikipmataram.ac.id
}

Sejarah Artikel

Dikirim: April 2021

Diterima: May 2021

Dipublikasi: June 2021

Kata Kunci

Modul PBL, Green

Chemistry, Literasi Sains,

Hidrolisis Garam

\begin{abstract}
Abstrak
Penelitian ini bertujuan untuk mengetahui pengaruh penggunaan modul PBL berorientasi green chemistry pada materi hidrolisis garam terhadap literasi sains siswa MAN 1 Mataram. Penelitian ini menggunakan rancangan eksperimen semu dengan desain pretest-postest control group design. Pengambilan sampel dilakukan menggunakan teknik cluster random sampling. Populasi dalam penelitian ini adalah seluruh siswa kelas XI MAN 1 Mataram dengan sampel penelitian yang digunakan adalah siswa kelas XI MIA 3 (kelas eksperimen) dan siswa kelas XI 2 (kelas kontrol). Teknik pengumpulan data literasi sains menggunakan tes pilihan ganda beralasan dan angket sikap siswa terhadap sains. Hasil uji prasyarat analisis menunjukkan data posttest terdistribusi normal dan homogen sehingga uji statistik yang digunakan adalah statistik parametrik $t$-test pooled varian dengan kriteria uji $\mathrm{t}$ dua pihak, dan diperoleh $t_{\text {hitung }}$ sebesar 2,88 dan $t_{\text {tabel }}$ sebesar 1,99 pada taraf signifikansi $5 \%$. Oleh karena itu $t_{\text {hitung }}>t_{\text {tabel }}$ maka $\mathrm{H}_{\mathrm{o}}$ ditolak dan $\mathrm{H}_{\mathrm{a}}$ diterima. Jadi, dapat disimpulkan bahwa terdapat pengaruh modul PBL berorientasi green chemistry terhadap literasi sains siswa di MAN 1 Mataram.
\end{abstract}

\section{The Effect of Green Chemistry Oriented Problem Based Learning Module on Salt Hydrolysis Material on Students' Science Literacy}

Article History

Received: April 2021

Accepted: May 2021

Published: June 2021

Key Words

Module PBL, Green

Chemistry, Science

Literacy, Salt Hydrolysis

How to cite this article?

\begin{abstract}
This study aimed to determine the effect of green chemistry-oriented PBL module on salt hydrolysis concepts to science literacy of MAN 1 Mataram students. This study used a quasi-experimental with pretest-postest control group design. Sampling was done using cluster random sampling technique. The population in this study was all students of class XI MAN 1 Mataram, with sample research used was the students of XIMIA 3 class (experimental class) and students of class XI 2 (control class). The technique of collecting science literacy data using multiple choice test was grounded. The result of prerequisite analysis test shows that posttest data were normal and homogeneous distributed so that the statistical test used was parametric statistic t-test pooled varian with $t$ test criteria of two parties, and it was obtained t count as 2.88 and t table 1.99 at the $5 \%$ significance level. Because of the calculated $>$ t-table then Ho was rejected and $\mathrm{Ha}$ accepted. So, it can be concluded that there was the influence of green chemistry oriented PBL module on student science literacy in MAN 1 Mataram.
\end{abstract}

Suryati, S., Hendrawani, H., \& Walidatun, N. (2021). Pengaruh Modul PBL Berorientasi Green Chemistry pada Materi Hidrolisis Garam terhadap Literasi Sains Siswa. Lensa: Jurnal Kependidikan Fisika, 9(1), 86-100. doi:https://doi.org/10.33394/j-1kf.v9i1.4343

\section{PENDAHULUAN}

Menurut Midllecamp dan Kean (1994), ilmu kimia memuat banyak konsep-konsep abstrak seperti simbol-simbol, struktur, reaksi-reaksi dan proses-proses kimia yang 
terstruktur sehingga sebagian besar siswa beranggapan bahwa kimia merupakan mata pelajaran yang sulit. Salah satu materi kimia yang dipelajari pada siswa kelas XI SMA yang di anggap sulit adalah materi hidrolisis garam. Pada pembelajaran hidrolisis garam siswa tidak hanya dituntut untuk mengetahui sifat larutan garam, siswa juga dituntut untuk menjelaskan mengapa larutan garam tesebut dapat bersifat asam, basa, netral serta perhitungan $\mathrm{pH}$ larutan berdasarkan hubungan $\mathrm{Ka}, \mathrm{Kb}, \mathrm{Kh}$ dan $\mathrm{Kw}$. Hal ini mengakibatkan siswa kurang memahami konsep kimia yang mendasar. Oleh karena itu, pembelajaran hidrolisis garam sebaiknya lebih menekankan pada proses perolehan konsep, sehingga siswa tidak hanya dapat menghitung $\mathrm{pH}$ tetapi juga dapat mengetahui konsep yang mendasari pada materi tersebut. Maka perlu adanya pengetahuan yang mendasar yang berkaitan materi dengan lingkungan.

Berdasarkan hasil observasi di MAN 1 Mataram diperoleh bahwa nilai MID semester siswa kelas XI belum mencapai ketuntasan klasikal minimal yaitu 85\% (Depdiknas, 2006) dalam kategori masih rendah. Hasil belajar kognitif siswa rendah karena pemahaman konsep siswa pada materi kimia belum matang. Menurut Isrotun, (2014) akar dari kurangnya pemahaman konsep siswa antara lain: 1) siswa kurang memikirkan konsep yang telah dipelajari sehingga konsep yang dipelajari tidak bertahan lama, 2) siswa enggan untuk memahami soal-soal latihan terlebih dahulu dalam mengerjakan soal dan beranggapan bahwa soal tersebut sulit untuk dikerjakan, 3) siswa sulit untuk mengaplikasikan materi dalam kehidupan sehari-hari.

Pemahaman konsep dalam ilmu kimia mengacu pada pemahaman konsep yang tersaji dalam tiga kategori representasi yang dikemukakan Johnstone (dalam Treagust et al., 2003), yaitu makroskopis, submikroskopis, dan simbolik. Representasi makroskopik merupakan level konkret, dimana pada level ini siswa mengamati fenomena yang terjadi, baik melalui percobaan yang dilakukan atau fenomena yang terjadi pada kehidupan sehari-hari. Fenomena yang diamati dapat berupa timbulnya bau, terjadinya perubahan warna, pembentukan gas dan terbentuknya endapan dalam reaksi kimia. Representasi mikroskopik merupakan level abstrak yang menjelaskan fenomena makroskopik. Representasi ini memberikan penjelasan pada level partikel dimana materi digambarkan sebagai susunan dari atom-atom, molekul-molekul dan ion-ion, sedangkan representasi simbolik digunakan untuk merepresentasikan fenomena makroskopik dengan menggunakan persamaan kimia, persamaan matematika, grafik, mekanisme reaksi, dan analogi-analogi (Chandrasegaran, Treagust, \& Mocerino 2007).

Kaitanya dengan literasi sains, dimana kerangka literasi kimia mencangkup pemahaman sifat alami dari suatu zat atau materi, reaksi kimia teori, laju kimia, dan aplikasi kimia secara umum dalam kehidupan sehari-hari. Literasi kimia perlu pemahaman dari komponen kimia dalam pembahasan isu-isu global yang berguna dalam membuat keputusan informasi yang berdampak pada masyarakat. Pembelajaran yang dapat membantu guru mengaitkan antara materi yang di ajarkan dengan situasi dunia nyata mendorong siswa membuat hubungan antara pengetahuan yang di milikinya dan penerapan dalam kehidupan sehari-hari sehingga dapat meningkatkan literasi sains siswa (literasi kimia) dan materi yang di berikan dapat lebih bermakna bagi siswa. Pemahaman kimia dan kemampuan untuk mengaplikasikan pemahaman dalam kehidupan sehari-hari, disebut literasi kimia (Tsaparlis, 2000) dalam (Suryati et al., 2017)

Literasi sains dalam PISA 2015 diartikan sebagai " the capacity to use scientific knowledge, to identify questions and to draw evidence-based conclusions in order to understand and help make decisions about the natural world and the changes made to it through human activity". Literasi sains didefinisikan sebagai kemampuan menggunakan pengetahuan sains, mengidentifikasi pertanyaan, dan menarik kesimpulan berdasarkan bukti-bukti, dalam rangka memahami serta membuat keputusan berkenaan dengan alam dan perubahan yang 
dilakukan terhadap alam melalui aktivitas manusia (Ahmadi et al., 2016). Literasi sains, termasuk literasi kimia, sangat perlu untuk diajarkan kepada siswa agar mereka dapat hidup di tengah-tengah masyarakat modern abad 21 (Rahayu, 2019). Pada abad ke-21 ini diperlukan siswa yang mampu memecahkan berbagai masalah dengan berpikir secara efektif dan memanfaatkan teknologi, khususnya di bidang pendidikan sains (Wicaksono et al., 2019) dalam (Suryati et al, 2020)

Literasi sains adalah kemampuan untuk menggunakan hubungan ilmu pengetahuan dengan isu-isu dan ide-ide tentang ilmu pengetahuan, sebagai masyarakat yang reflektif. Literasi sains diharapkan peserta didik mampu memenuhi berbagai tuntutan zaman yaitu menjadi problem solver dengan pribadi yang kompetitif, inovatif, kreatif, kolaboratif, serta berkarakter. Hal tersebut dikarenakan penguasaan kemampuan literasi sains dapat mendukung pengembangan dan penggunaan kompetensi (Yuliati, 2017).

Literasi sains penting untuk dikuasai oleh siswa dalam kaitannya dengan bagaimana siswa dapat memahami lingkungan hidup (OECD 2013). Pembelajaran yang dimaksudkan adalah pembelajaran yang tetap memperhatikan aspek-aspek lingkungan, sehingga kemampuan literasi sains siswa dapat mendukung dalam lingkungan sekitar bukan untuk merusak lingkungan sekitar.

Menyinggung masalah lingkungan, maka tidak terlepas dari istilah pencemaran dan perusakan yang disebabkan oleh bahan-bahan kimia yang berbahaya. Untuk mengatasi hal tersebut muncul istilah green chemistry. (Andrew et al., 2014) menyatakan bahwa "green chemistry secara efesien menggunakan bahan mentah yang disukai, menghilangkan limbah, menghindari penggunaan pereaksi dan pelarut beracun atau berbahaya dalam pembuatan dan penerapan produk kimia. Green chemistry adalah penggunaan tehnik dan metode secara kimia untuk mengurangi atau mengeliminasi penggunaan bahan dasar, produk, produk samping, pelarut, pereaksi, yang berbahaya bagi kesehatan manusia dan lingkungan (Nurbaity, 2011).

Dari beberapa teori di atas dapat disimpulkan bahwa green chemistry merupakan suatu konsep kimia dalam mendesain, mengembangkan, dan mengimplementasikan produk dan proses yang memiliki tingkat pencemaran yang kecil bahkan tidak mencemari sama sekali terhadap lingkungan dan kesehatan manusia.

Dalam (Andrew et al., 2014) mengembangkan 12 prinsip green chemistry yang berfungsi sebagai panduan pengaplikasian green chemistry dalam tindakan nyata. Kedua belas prinsip tersebut adalah: (1) Mencegah limbah lebih baik daripada mengolah dan membersihkannya (2) Ekonomi atom, metoda sintesis yang efisien. (3) Melakukan sintesis kimia yang tak menghasilkan racun (4) Mendesain senyawa kimia yang tak beracun (5) Pemakaian pelarut dan bahan bahan yang aman (6) Mendesain pemakaian energi yang efesien (7) Pemakaian bahan baku yang dapat diperbaharui (8) Mengurangi senyawa turunan yang tak perlu (9) Pemakaian katalis sangat baik secara stokiometris (10) Mudah terdegradasi (11) Pencegahan polusi lingkungan (12) Pencegahan terhadap kecelakaan.

Beberapa prinsip green chemistry yang dapat diaplikasikan dalam dunia pendidikan adalah mencegah limbah lebih baik daripada mengolah dan membersihkannya, penggunaan pelarut dan zat tambahan yang aman, penggunaan bahan baku yang dapat diperbaharui, pencegahan polusi lingkungan, dan mudah terdegradasi (Fauziah at al., 2016).

Pembelajaran yang sesuai untuk tujuan di atas adalah suatu pembelajaran yang dapat mengaitkan kemampuan literasi sains siswa tetapi tetap memperhatikan kesadaran akan lingkungan sekitarnya. Model pembelajaran yang mampu untuk menumbuhkan literasi sains dengan menghubungkan materi kimia yaitu dengan Model Problem Based 


\section{Learning (PBL).}

PBL yang diorientasikan dengan green chemistry akan menjadikan siswa mampu mengidentifikasikan masalah di lingkungan dan lebih kreatif dalam mencari solusi serta mampu mengaplikasikan pengetahuan yang mereka miliki dalam konteks permasalahan yang mereka hadapi. Menurut (Rosita et al., 2014), model PBL yang diorientasikan dengan green chemistry ini membawa siswa lebih kreatif, memiliki kepedulian terhadap lingkungan yang besar, lebih mudah mengaplikasikan materi-materi yang dipelajari untuk memahami dan memberi solusi terhadap masalah yang terjadi di lingkungan, memiliki nilai-nilai konservasi terhadap lingkungan.

Berdasarkan uraian yang telah dipaparkan sebelumnya, telah dikembangkan Modul Problem Based Learning (PBL) Beroreantasi Green Chemistry pada Materi Hidrolisis Garam untuk Meningkatkan Literasi Sains (Fuziah et al., 2016) dengan hasil validasi dan uji coba terbatas sudah dikatakan layak, sehingga dari penelitian ini bisa dilanjutkan ke skala luas dengan tujuan menguji pengaruh modul PBL beroreantasi green chemistry pada materi hidrolisis garam terhadap literasi sains siswa.

\section{METODE PENELITIAN}

Penelitian ini menggunakan metode eksperimen semu (quasy experimen), dengan desain penelitian pretest-posttest control group design. Tabel 1 menunjukkan desain penelitian ini.

Tabel 1 Desain Penelitian

\begin{tabular}{lccc}
\hline Kelas & Pretest & Perlakuan & Posttest \\
\hline Eksperimen & $\mathrm{O}_{1}$ & $\mathrm{X}_{1}$ & $\mathrm{O}_{2}$ \\
Kontrol & $\mathrm{O}_{3}$ & $\mathrm{X}_{2}$ & $\mathrm{O}_{4}$ \\
\hline
\end{tabular}

(Diadaptasi dari Setyosari, 2016)

Populasi yang digunakan dalam penelitian ini adalah seluruh siswa kelas XI (kelas XI MIA 1 sampai XI MIA 3) MAN 1 Mataram yang berjumlah 107 siswa. Adapun teknik pengambilan sampel yang digunakan yaitu dengan teknik cluster random sampling, karena sampel penelitian berupa unit-unit rumpun (kelas) yang dipilih secara acak dalam populasi. Adapun sampel yang terpilih dalam penelitian ini melalui uji homogenitas yaitu kelas XI MIA 3 sebagai kelas eksperimen berjumlah 39 siswa dan kelas XI MIA 2 sebagai kelas kontrol berjumlah 37 siswa.

Instrumen dalam penelitian ini dibagi menjadi dua yakni instrumen perlakuan dan instrumen pengukuran. Instrumen perlakuan terdiri dari silabus, RPP, dan modul. Instrumen pengukuran yaitu angket sikap siswa terhadap sains dan tes soal pilihan ganda beralasan.

\section{Teknik Pengumpulan Data}

\section{Angket Siswa terhadap Sains}

Angket sikap siswa terhadap sains digunakan untuk mengetahui sikap siswa terhadap sains. Angket siswa terhadap sains digunakan pada pertemuan pertama dan pertemuan terakhir di kelas ekserimen dan kontrol.

\section{Tes Pilihan Ganda Beralasan}

Data literasi sains diperoleh dengan menggunakan tes pilihan ganda beralasan. Pemilihan instrumen ini karena jawaban siswa tidak hanya dilihat dari pilihan saja melainkan juga pada alasannya. Tes ini akan diberikan pada akhir pembelajaran pada kelas eksperimen maupun kelas kontrol. 


\section{Teknik Analisis Data}

Analisis Data Angket Siswa terhadap Sains

Angket siswa terhadap sains digunakan untuk menganalisis tanggapan siswa terhadap isu-isu sains. Analisis data dilakukan dengan menghitung presentase masingmasing jawaban untuk setiap pertanyaan dalam angket. Pemberian skor kepada setiap pertanyaan siswa dengan ketentuan seperti pada Tabel 2.

Tabel 2 Pemberian Skor Tanggapan Siswa

\begin{tabular}{ccc}
\hline Skor & Pertanyaan Positif & Pertanyaan Negatif \\
\hline Sangat Setuju (SS) & 4 & 1 \\
Setuju (S) & 3 & 2 \\
Tidak Setuju (TS) & 2 & 3 \\
Sangat Tidak Setuju (STS) & 1 & 4 \\
\hline
\end{tabular}

Tabel 3 Kriteria Sikap Siswa terhadap Sains

\begin{tabular}{cc}
\hline Tingkat Pencapaian (\%) & Kualifikasi \\
\hline $81-100$ & Sangat tinggi \\
$61-80$ & Tinggi \\
$41-60$ & Cukup \\
$21-40$ & Rendah \\
$0-20$ & Sangat rendah \\
\hline
\end{tabular}

(Sumber: Muriati, 2014 dalam Ahmadi et al., 2016)

Analisis Data Literasi Sains

Adapun analisis data dalam penelitian ini yaitu analisis data literasi sains diukur dengan menggunakan tes pilihan ganda beralasan. Rubrik penilaian literasi sains siswa ditunjukkan pada Tabel 4 berikut:

Tabel 4. Rubrik Penilaian Tingkat Literasi Sains Siswa

\begin{tabular}{|c|c|}
\hline Skor & Keterangan \\
\hline 0 & Apabila jawaban salah \\
\hline 1 & Apabila jawaban benar tanpa alasan \\
\hline 2 & Apabila jawaban benar, alasan benar tetapi tidak sesuai hubungannya \\
\hline 3 & Apabila jawaban benar, alasan benar dan berhubungan \\
\hline
\end{tabular}

$$
\text { Nilai }=\frac{\text { jumlah skor perolehan }}{\text { skor maksimum }} \boldsymbol{x} 100
$$

Tehnik analisis data yang digunakan untuk mengetahui pengaruh penggunaan modul Problem Based Learning beroriantasi Green Chemistry pada materi hidrolisis garam terhadap literasi sains siswa, maka data tes akhir (objektif) akan dianalisis dengan menggunakan rumus $t$-test polled varians.

\section{HASIL DAN PEMBAHASAN}

\section{Hasil Penelitian}

\section{Hasil angket sikap siswa terhadap sains.}

Data mengenai sikap siswa terhadap sains diperoleh melalui hasil angket sikap siswa terhadap sains yang dapat dilihat di bawah ini, data selengkapnya dapat dilihat pada Tabel 5. 
Tabel 5. Angket Siswa Terhadap Sains

\begin{tabular}{|c|c|c|c|c|c|}
\hline \multirow{3}{*}{ No } & \multirow{3}{*}{ Aspek } & \multicolumn{2}{|c|}{ Eksperimen } & \multicolumn{2}{|c|}{ Kontrol } \\
\hline & & \multicolumn{4}{|c|}{ Pertemuan } \\
\hline & & Pretest & Posttest & Pretest & Posttest \\
\hline 1 & Jumlah Siswa & 37 & 39 & 33 & 36 \\
\hline 2 & Total Skor & 2944 & 3350 & 2615 & 3039 \\
\hline 3 & Persentase & 79,56 & 85,90 & 79,24 & 84,41 \\
\hline 4 & Kategori & Tinggi & Sangat Tinggi & Tinggi & Sangat Tinggi \\
\hline
\end{tabular}

\section{Analisis Data Literasi Sains Siswa}

Analisis Data Pre-Test

Data Literasi sains siswa diperoleh dari nilai hasil tes pilihan ganda beralasan yang diberikan sebelum kegiatan pembelajaran dilakukan. Hasil pre-tes literasi sains pada kelas eksperimen dan kontrol dapat dilihat pada tabel 6 berikut ini:

Tabel 6. Hasil Pre-Test Kelas Eksperimen dan Kelas Kontrol

\begin{tabular}{lcc}
\hline \multirow{2}{*}{ Deskripsi } & \multicolumn{3}{c}{ Pre-test } \\
\cline { 2 - 3 } & Kontrol & Eksperimen \\
\hline Jumlah siswa & 33 & 37 \\
Rata-rata & 19,48 & 22,89 \\
Nilai tertinggi & 39 & 37 \\
Nilai terendah & 4 & 6 \\
\hline
\end{tabular}

Berdasarkan Tabel 6 di atas terlihat bahwa nilai rata-rata kelas kontrol dan eksperimen yaitu 19,48 dan 22,89 dengan selisih nilai rata-rata Pre-test kedua kelas tersebut adalah 3,41 .

\section{Uji Homogenitas Data Pre-Test}

Uji homogenitas data hasil Pre-test menggunakan uji-F dengan taraf signifikan $5 \%$. Hasil yang diperoleh $\mathrm{F} \_$hitung $<\mathrm{F} \_t a b e l$. Berdasarkan kriteria pengambilan keputusan, maka kedua sampel berasal dari populasi yang homogen. Hal ini menunjukkan bahwa kemampuan awal literasi sains siswa kelas eksperimen dan kontrol sama.

Analisis Data Post-Test

Tes Akhir (Post-Test) bertujuan untuk mengetahui kemampuan akhir kedua kelas setelah diberikan perlakuan yang berbeda. Berdasarkan hasil tes akhir pada kelas eksperimen dan kelas kontrol dapat dilihat pada tabel 7 sebagai berikut:

Tabe1 7. Hasil Post-Test Kelas Eksperimen dan Kelas Kontrol

\begin{tabular}{ccc}
\hline \multirow{2}{*}{ Nilai } & \multicolumn{3}{c}{ Kelas } \\
\cline { 2 - 3 } & Kontrol & Eksperimen \\
\hline Jumlah siswa & 36 & 39 \\
Rata-rata & 72,75 & 77,28 \\
Tertinggi & 91 & 93 \\
Terendah & 57 & 59 \\
\hline
\end{tabular}

Dari Tabel 7 di atas terlihat bahwa rata-rata nilai kelas ekperimen 77,28 dan ratarata nilai kelas kontrol 72,75 , dengan selisih nilai rata-rata kedua kelas tersebut adalah 4,53 .

Uji Homogenitas Post-test

Uji homogenitas data hasil post-test digunakan untuk mengetahui tindak lanjut uji hipotesis (t-test) yang digunakan. Uji homogenitas ini menggunakan uji-F dengan taraf 
signifikansi 5\%. Hasil perhitungan uji homogenitas hasil post-test siswa dapat dilihat dalam Tabel 8 berikut.

Tabel 8. Uji Homogenitas Data Hasil Post-test

\begin{tabular}{lcccc}
\hline \multicolumn{1}{c}{ Kelompok } & Varians $\left(S^{2}\right)$ & $\mathrm{F}_{\text {hitung }}$ & $\mathrm{F}_{\text {tabel }}(\alpha=0.05)$ & Uji Homogenitas \\
\hline Eksperimen & 91,10 & 1,00 & 1,76 & Homogen \\
Kontrol & 91,22 & 1,00 & & \\
\hline
\end{tabular}

Berdasarkan Tabel 8 tersebut terlihat bahwa $F_{\text {hitung }}<F_{\text {tabel }}$ yaitu $1,00<1,76$ maka kedua sampel berasal dari populasi yang homogen.

Uji Normalitas Data Post-Test

Uji normalitas dilakukan terhadap data hasil post-test kelas eksperimen dan kelas kontrol untuk mengetahui apakah data akhir kedua kelas terdistribusi normal atau tidak normal. Uji normalitas dihitung menggunakan rumus chi kuadrat pada taraf signifikan 5\% dengan derajat kebebasan $\mathrm{dk}=\mathrm{Bk}-1=6-1=5$, dengan $\mathrm{Bk}$ adalah banyak kelas. Hasil perhitungan uji normalitas data hasil post-test kedua kelas dapat dilihat dalam Tabel 9 berikut.

Tabel 9. Hasil Perhitungan Normalitas Post-test

\begin{tabular}{lccc}
\hline \multicolumn{1}{c}{ Kelompok } & $\chi^{2}{ }_{\text {hitung }}$ & $\chi_{\text {tabel }}(\alpha=0,05)$ & Hasil Uji Normalitas \\
\hline Eksperimen & 9,63 & 11,070 & Normal \\
Kontrol & 6,88 & 11,070 & Normal \\
\hline
\end{tabular}

Berdasarkan tabel di atas, dapat dilihat bahwa $\chi^{2}{ }_{\text {hitung }}<\chi_{\text {tabel }}^{2}$. Hal ini menunjukkan bahwa data kedua kelas terdistribusi normal.

\section{Uji Hipotesis Literasi Sains}

Berdasarkan hasil perhitungan diketahui bahwa data kedua kelas terdistribusi normal dan homogen serta jumlah siswa untuk kelas eksperimen dan kontrol berbeda, maka uji hipotesis yang digunakan adalah statistik parametrik berupa $t$-test polled varians dapat dilihat dalam tabel 10 berikut.

Tabel 10. Hasil Uji Hipotesis literasi sains

\begin{tabular}{lccccc}
\hline \multicolumn{1}{c}{ Kelompok } & Jumlah Siswa $(\boldsymbol{n})$ & Rata $-\operatorname{rata}(\overline{\boldsymbol{x}})$ & Varians $\left(\boldsymbol{s}^{2}\right)$ & $\boldsymbol{t}_{\text {hitung }}$ & $\boldsymbol{t}_{\text {tabel }}$ \\
\hline Eksperimen & 39 & 77,28 & 91,10 & \multirow{2}{*}{2,03} & 1.99 \\
Kontrol & 36 & 72,75 & 91,22 & & \\
\hline
\end{tabular}

Berdasarkan kriteria pengujian $t_{\text {hitung }}>t_{\text {tabel }}$, yaitu 2,03 $>1,99$ sehingga dapat disimpulkan $\mathrm{Ha}$ diterima dan $\mathrm{H}_{0}$ ditolak.

\section{Pembahasan}

Penggunaan Modul PBL Berorientasi Green Chemistry pada Materi Hidrolisis Garam terhadap Literasi Sains Siswa

Nilai rata-rata literasi sains siswa kelas eksperimen lebih tinggi dari nilai rata-rata kelas kontrol (Lihat tabel 7). Analisis data yang digunakan pada uji hipotesis adalah uji t berupa ( $t$-test polled varians). Dari hasil uji hipotesis tersebut diperoleh $t$ hitung $>t$ tabel, yaitu 2,03 > 1,99 sehingga dapat disimpulkan $\mathrm{Ha}$ diterima dan $\mathrm{H}_{0}$ ditolak. Ringkasan tingkat literasi sains siswa dapat dilihat pada Gambar 1 berikut. 


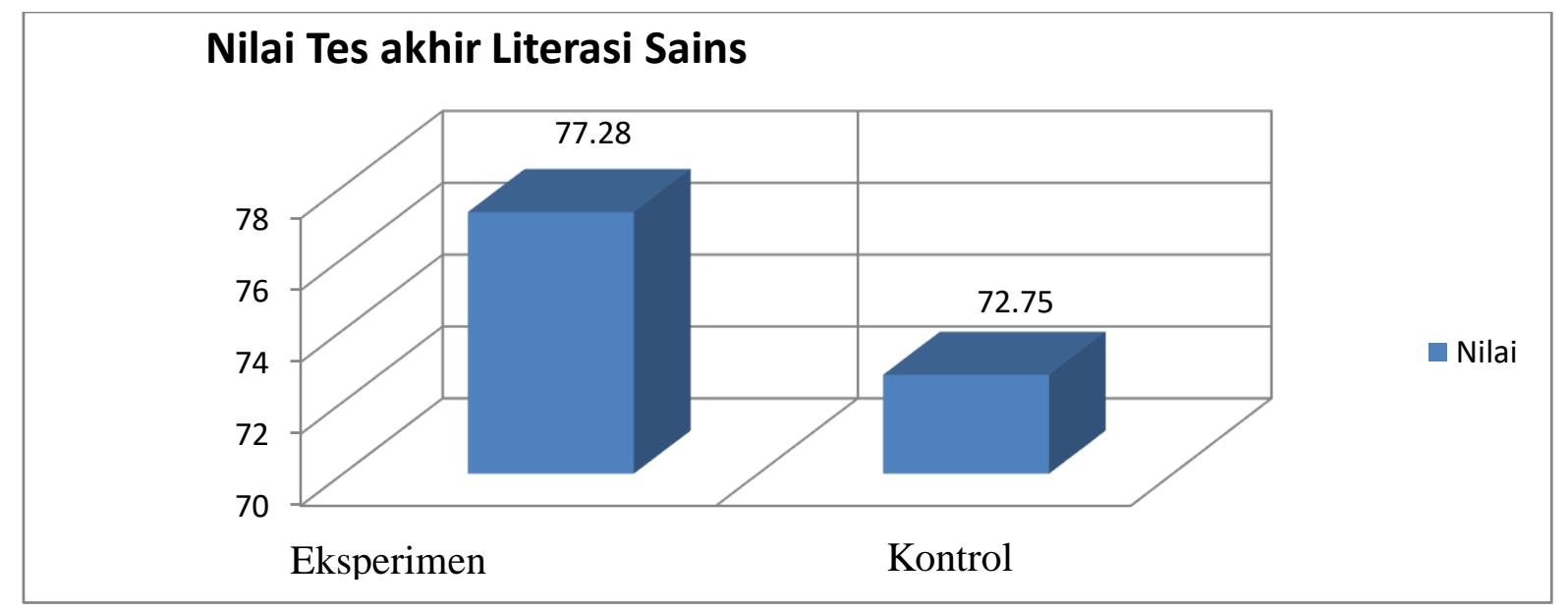

Gambar 1. Diagram Literasi Sains Siswa

Berdasarkan gambar 1 dapat dilihat bahwa rata-rata literasi sains siswa kelas eksperimen lebih tinggi dibandingkan kelas kontrol. Hal ini dapat dilihat pada gambar 2.a jawaban kelas kontrol dan gambar 2.b jawaban kelas eksperimen pada soal literasi sains.

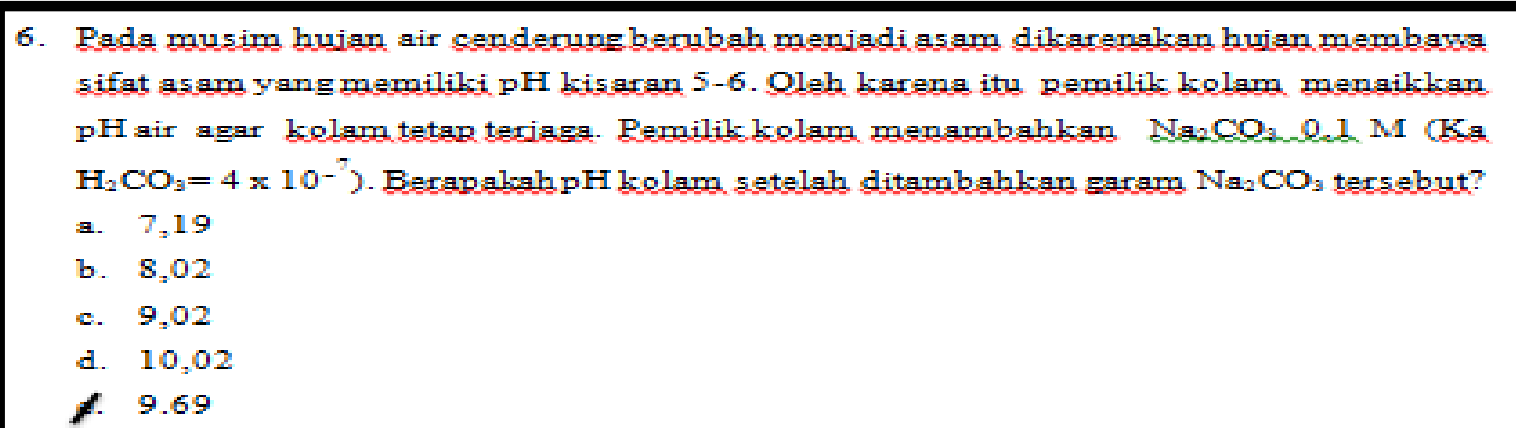

$$
\begin{aligned}
& \text { 1asan } \\
& K C_{2}=\frac{\mathrm{kw}}{\mathrm{ka}}=\frac{1 \times 10^{24}}{4 \times 10^{-7}}=0,25 \times 10^{-7} \\
& \mathrm{pH}=-\log O \mathrm{H}^{\prime}
\end{aligned}
$$

Gambar 2.a Jawaban Kelas Kontrol

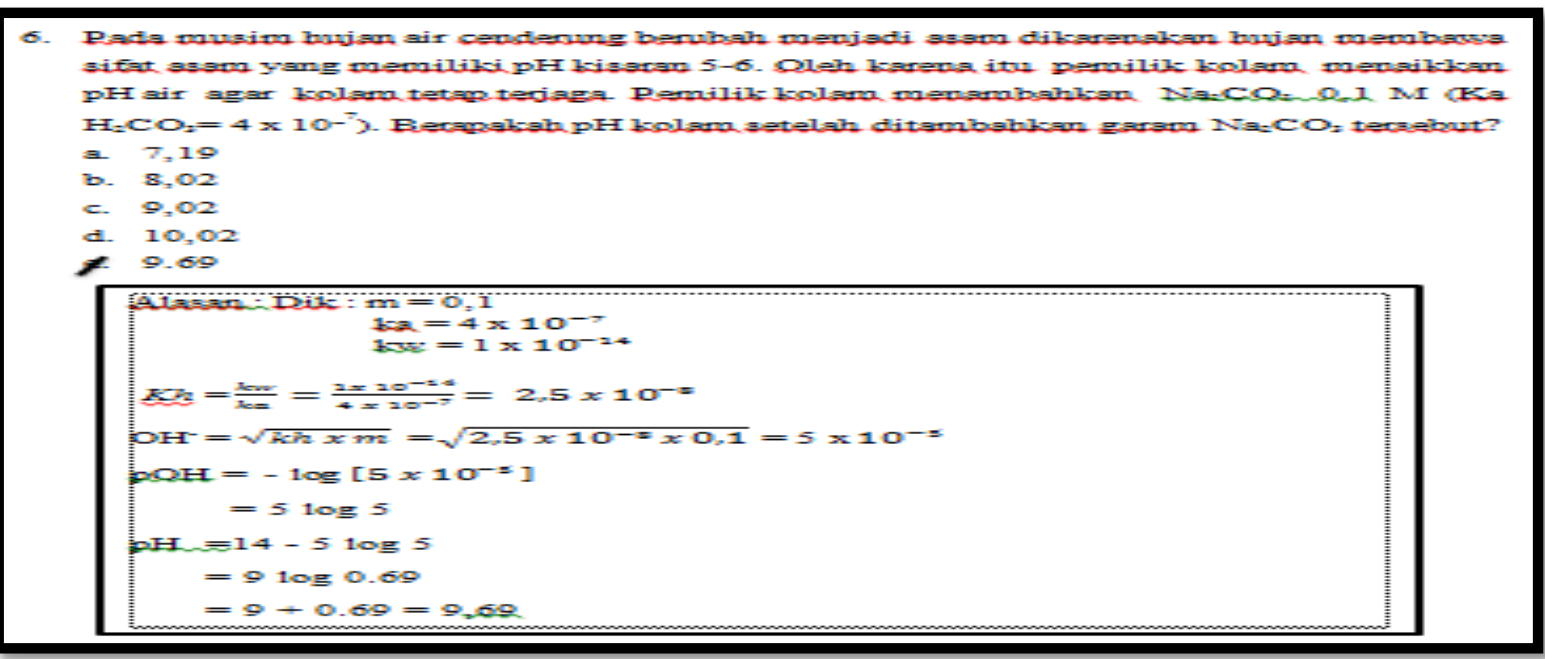

\section{Gambar 2.b Jawaban Kelas Eksperimen}


Berdasarkan Gambar 2.a dan Gambar 2.b pada indikator literasi sains analisis dan menginterpretasikan data dan menarik kesimpulan pada soal nomor 6 , jawaban siswa pada kelas kontrol hanya dapat menjawab pilihan ganda tetapi tidak dapat menjawab alasannya, sedangkan kelas eksperimen bisa menjawab pilihan ganda dan alasannya. Hal ini dikarenakan pada saat perlakuan: pada kelas eksperimen menggunakan modul PBL berorientasi green chemistry sedangkan kelas kontrol menggunakan sumber belajar yang biasa guru kimia gunakan di kelas. Pembelajaran pada kelas eksperimen yang menekankan pada literasi sains siswa dengan menggunakan modul dan disesuaikan dengan model PBL berorientasi green chemistry. Model PBL dapat mengaitkan materi pelajaran dengan kehidupan dunia nyata. PBL memiliki 5 komponen utama pembelajaran yaitu: 1) Proses pemecahan masalah 2) Mengorganisasikan siswa pada masalah 3) Proses penyelidikan 4) Mengembangkan dan menyajikan hasil 5) Mengevaluasi hasil dari pemecahan masalah.

Pembelajaran yang melibatkan siswa secara langsung dan berkelompok, siswa dilatih untuk bekerjasama dan bertanggungjawab sehingga pembelajaran yang disajikan lebih atraktif. Hal ini sesuai dengan kelebihan PBL sendiri yaitu menantang kemampuan siswa serta memberikan kepuasan untuk menemukan pengetahuan baru bagi siswa, meningkatkan motivasi dan aktivitas belajar siswa, membantu siswa dalam menstransfer pengetahuan siswa untuk memahami masalah dunia nyata, membantu siswa untuk mengembangkan pengetahuan barunya dan bertanggungjawab dalam pembelajaran yang mereka lakukan. Hal ini sangat penting, sebab dengan dapat mengorelasikan materi yang ditemukan dengan kehidupan nyata. Hasil penelitian ini diperkuat oleh Dasna dan Sutrisno (2007) dalam (Rosy et al., 2015) Problem Based Learning merupakan pelaksanaan pembelajaran berangkat dari sebuah kasus tertentu dan kemudian dianalisis lebih lanjut untuk ditemukan pemecahan masalahnya, dan merupakan salah satu model pembelajaran inovatif yang dapat memberikan kondisi belajar aktif pada siswa.

Modul berorientasi green chemistry bertujuan agar siswa memiliki karakter peduli lingkungan, khususnya dalam penanganan masalah lingkungan, membentuk perilaku agar dapat berpartisipasi dalam pemeliharaan lingkungan yang akan berdampak positif pada kemampuan literasi sains siswa. Prinsip green chemistry yang digunakan dalam modul PBL ada 6 yaitu fokus prinsip green chemistry yang dijadikan fokus utama dalam penelitian ini adalah:

1) Mencegah limbah lebih baik daripada mengolah dan membersihkannya contohnya menggunakan cangkang kulit kerang sebagai pembuatan $\mathrm{CaCO}_{3}$, untuk menjernihkan air sungai yang tercemar.

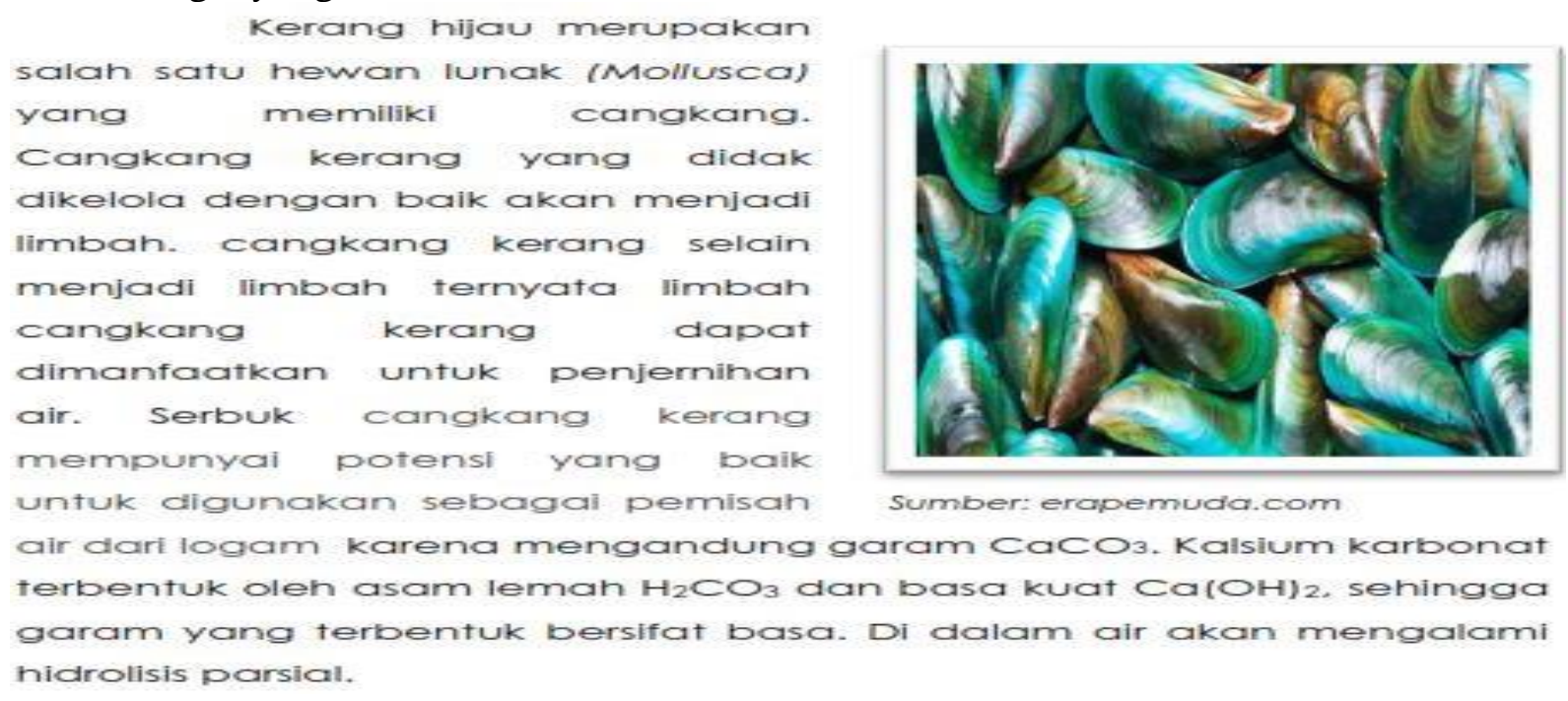


2) Pembuatan produk kimia yang aman dari bahan yang dapat diperbaharui, contohnya pembuatan MSG berbahan baku tomat untuk meminimalisir toksisitas (tingkat beracun).

\section{Pembuatan MSG Aman Berbahan Tomat}

Pada proses pembuatan MSG dari tomat tidak menggunakan proses kimia ataupun fermentasi. MSG hasil inovasi cukup menggunakan tehnik yang sederhana. Proses pertama hanya menggunakan proses penjemuran dibawah sinar matahari sehingga menjadi kering. proses ini berfungsi untuk menghilangkan kadar air yang cukup banyak pada buah tomat. Kemudian untuk menjadikan MSG

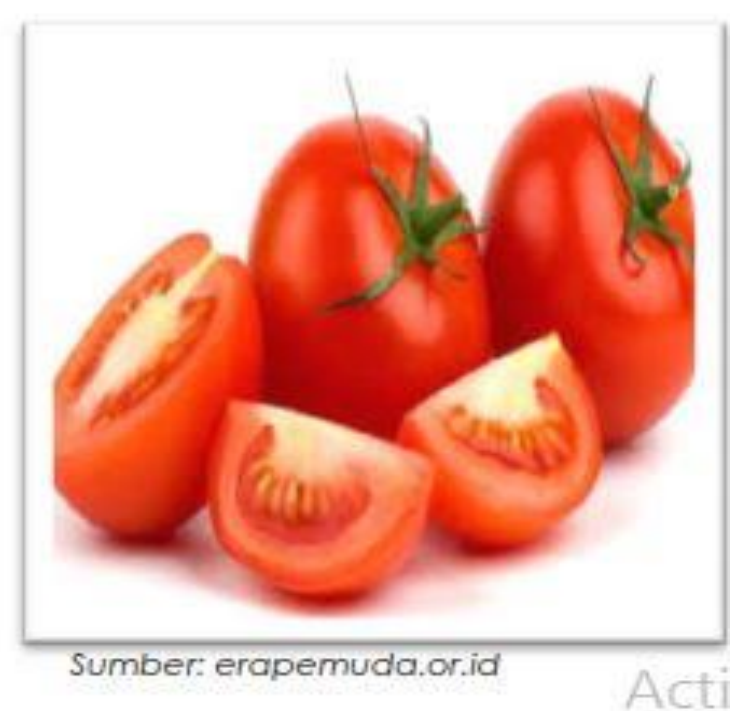

3) Pemakaian pelarut dan bahan bahan yang aman, misalnya pembuatan cat dari $\mathrm{CaCO}_{3}$ yang berasal dari cangkang kerang.

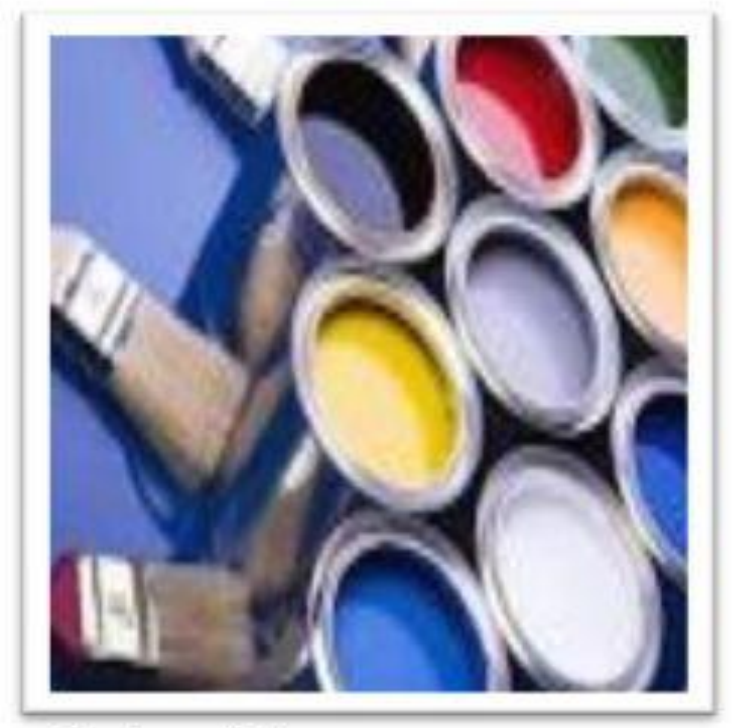

Sumber: alibaba.com

Pernahkah anda membuat cat? Ternyata membuat cat sendiri sangat mudah. Pembuatan cat ini berbeda dari pembuatan cat pada pabrikpabrik pada umumnya. Tentunya sangat menyenangkan dan bermanfaat apabila cat yang dihasikan merupakan olahan dari bahan-bahan alam yang tentunya lebih ramah lingkungan.

Untuk mengalahkan cat hasil buatan pabrik yang berlebel cat berkualitas tinggi tentunya tidak

4) Melakukan sintesis kimia yang tak menghasilkan racun, misalnya pembuatan deterjen dari daun waru yang banyak mengandung sapoin. 


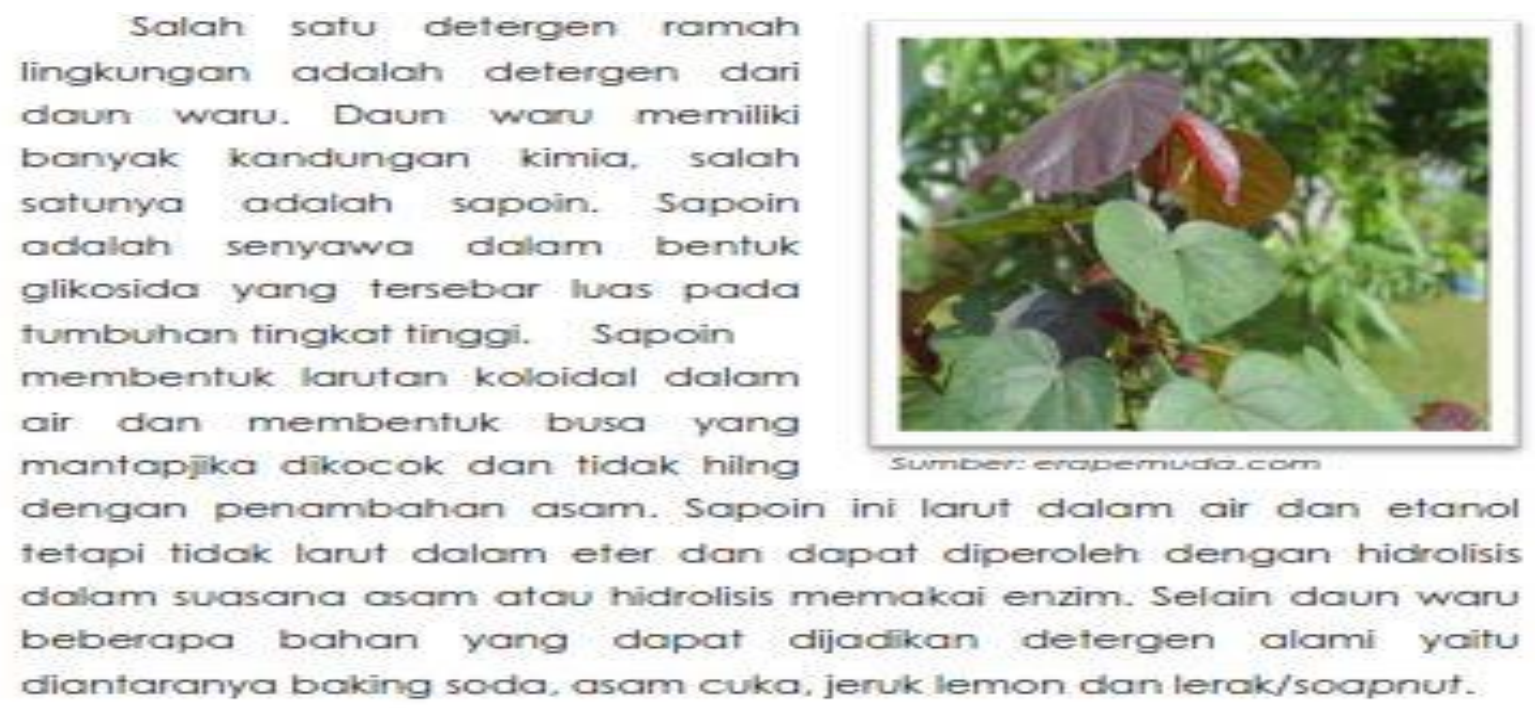

5) Mudah terdegradasi

Misalnya limbah cair atau padatan dari hasil pembuangan rumah tangga atau industri yang mempunyai kandungan nitrogen yang cukup tinggi dan kandungan C-organik yang cukup yang dapat menjadikan limbah MSG tersebut dapat digunakan sebagai pupuk yang sangat bermanfaat dan berkualitas tinggi.

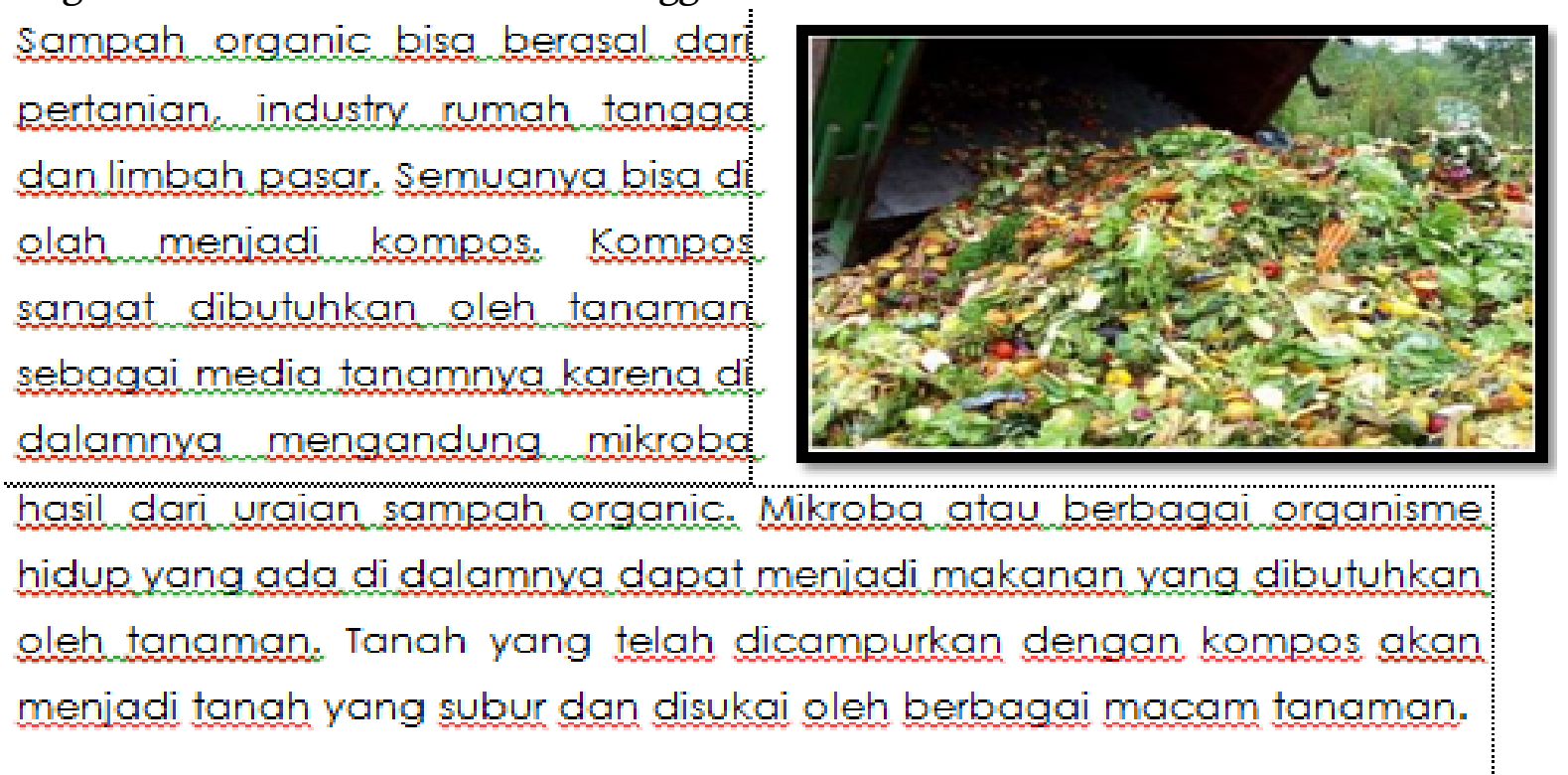

6) Pencegahan polusi lingkungan dalam upaya pencegahan terjadinya pencemaran lingkungan dan dampak negatif lainnya, contohnya untuk menanggulangi terjadinya hujan asam akibat pemakaian bahan bakar yang mengakibatkan polusi lingkungan perlu penggantian bahan bakar dengan kandungan belerang rendah seperti penggunaan bahan bakar hidrogen, pengendalian pencemaran selama pembakaran, menambahkan zat kapur (garam $\mathrm{CaCO}_{3}$ ) dalam tanah dan perairan serta melakukan reboisasi.

Adanya konsep green chemistry ini dapat menimbulkan suasana baru dengan melibatkan lingkungan secara langsung dalam setiap kegiatan belajar dan membentuk peserta didik yang perduli terhadap lingkungan sedangkan pada kelas kontrol pembelajaran masih menggunakan buku paket kimia yang masih kurang mengintegrasikan antara materi pembelajaran dengan kehidupan dunia nyata. Hal ini 
mengakibatkan nilai literasi sains siswa kelas eksperimen lebih tinggi dibandingkan dengan kelas kontrol.

Pembelajaran menggunakan modul PBL berorientasi green chemistry berdampak positif terhadap literasi sains siswa. Hal ini dapat dilihat dari uji hipotesis pada tabel 10 dimana terdapat pengaruh yang signifikan antara kelas kontrol dan kelas eksperimen. Hal ini dikarenakan Penggunaan modul PBL berorientasi green chemistry yang digunakan mampu menarik minat siswa selama proses pembelajaran. Hal ini diperkuat oleh (Yuliani et al., 2016) dalam penelitiannya mengatakan bahwa Penerapan Pembelajaran IPA Berbasis Keterampilan Proses Sains untuk Meningkatkan Literasi Sains yaitu "Terdapat perbedaan peningkatan literasi sains siswa yang signifikan antara kelas eksperimen dengan kelas kontrol. Rata-rata nilai $N$-Gain kelas eksperimen sebesar 0,3239 menunjukkan kriteria sedang, dan rata-rata nilai $N$-Gain kelas kontrol sebesar 0,2332 menunjukkan kriteria rendah".

Aspek dalam literasi sains yang didapatkan siswa dengan modul pembelajaran PBL berorientasi green chemistry ini meliputi aspek konteks, aspek pengetahuan, aspek kompetensi dan aspek sikap. Aspek konteks terdiri dari beberapa pemahaman ilmu pengetahuan dan teknologi yang bersifat individual dan lokal yang terdapat dalam modul yang dikembangkan. Aspek pengetahuan merujuk pada konsep-konsep kunci dari sains yang diperlukan untuk memahami fenomena alam dan perubahan yang dilakukan terhadap alam melalui aktivitas manusia. Aspek pengetahuan terdiri dari, isi pengetahuan, pengetahuan prosedural dan pengetahuan epistemik. Selanjutnya aspek kompetensi diantaranya menjelaskan fenomena secara saintifik, mengevaluasi dan merancang penyelidikan ilmiah, dan menafsirkan data dan bukti secara ilmiah terdapat dalam modul pada bagian rumusan masalah dengan menjawab hipotesis dan melakukan kegiatan percobaan sehingga akan mendapatkan bukti secara ilmiah. Aspek yang digunakan untuk instrumen literasi sains yaitu Kompetensi literasi sains:

1. Menjelaskan fenomena sains dengan indikator:

a. Mengidentifikasi, menggunakan dan menyimpulkan metode/model yang sesuai pada soal nomor 4 , dan 16

b. Membuat dan membenarkan prediksi yang tepat pada soal nomor 2

c. Menjelaskan implikasi potensi ilmiah bagi masyarakat sesuai pada soal nomor 1, 9, 14, dan 15.

2. Evaluasi dan merancang penyelidikan ilmiah dengan indikator :

a. Mengidentifikasi pertanyaan eksplorasi dalam sebuah penelitian ilmiah yang diberikan pada soal nomor 10 .

3. Menginterpretasi data dan bukti ilmiah dengan indikator :

a. Mengidentifikasi asumsi, bukti dan penalaran dalam ilmu terkait pada soal nomor 3 dan 8

b. Analisis dan menginterpretasikan data dan menarik kesimpulan pada soal nomor 5 , 6, 7, 11, 12, dan 13 .

Angket Sikap Siswa Terhadap Sains

Angket siswa terhadap sains digunakan untuk mengukur minat siswa dalam sains.

Pada tabel 5 dapat dilihat bahwa kelas eksperimen lebih tinggi nilai rata-ratanya dibandingkan kelas kontrol. Perbandingan nilai rata-rata kedua kelas dapat dilihat pada Gambar 3 berikut. 


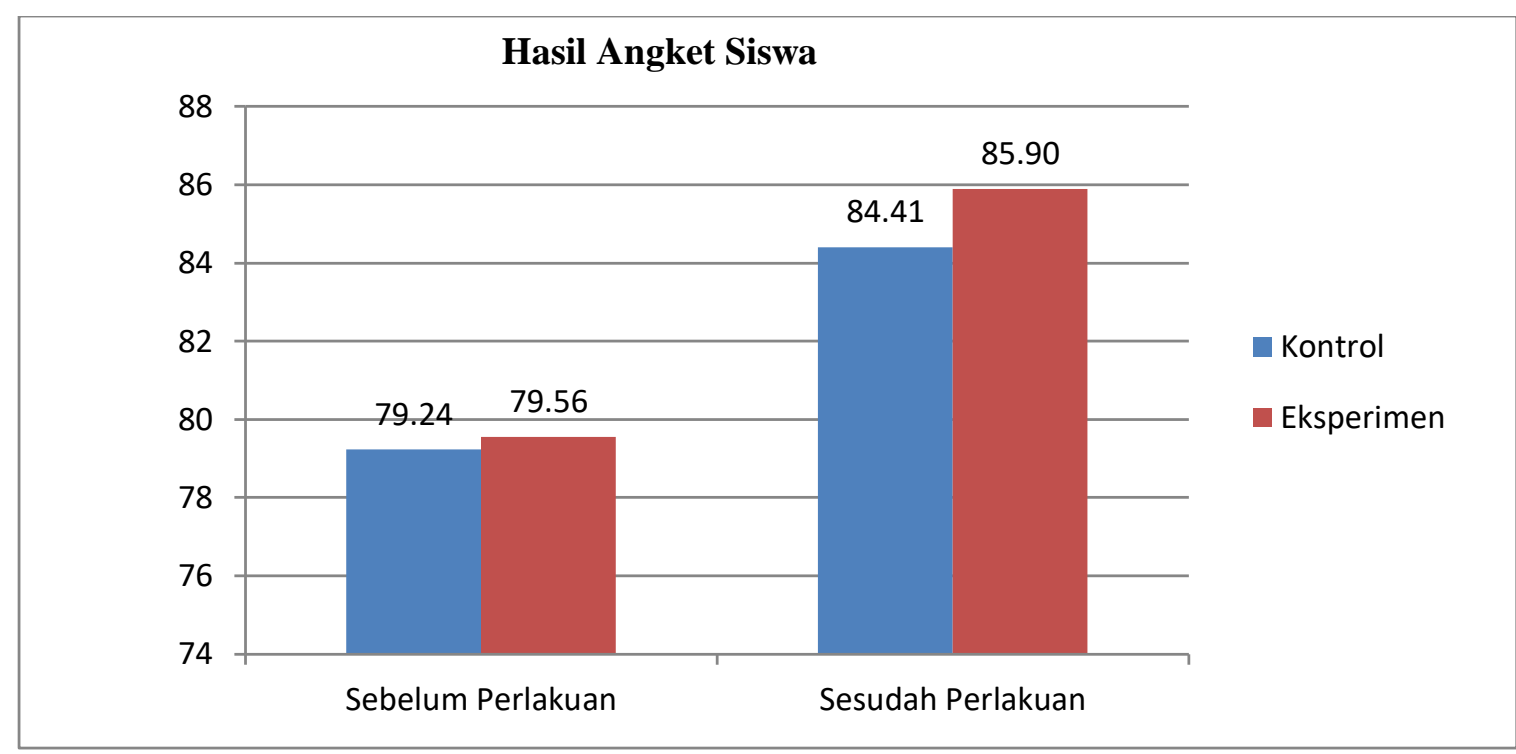

Gambar 3. Diagram Perbandingan Angket

Pada Gambar 3 dapat dilihat bahwa hasil angket minat siswa terhadap sains kelas eksperimen lebih tinggi dibandingkan kelas kontrol sebelum dan setelah diberikan perlakuan. Nilainya meningkat secara signifikan setelah diberikan perlakuan. Hal ini disebabkan oleh pembelajaran pada kelas eksperimen menggunakan modul PBL berorientasi green chemistry sedangkan kelas kontrol menggunakan buku paket kimia yang biasa digunakan di sekolah. Pembelajaran menggunakan modul PBL berorientasi green chemistry bertujuan agar siswa memiliki karakter peduli lingkungan, khususnya dalam penanganan masalah lingkungan, membentuk perilaku agar dapat berpartisipasi dalam pemeliharaan lingkungan yang akan berdampak positif pada kemampuan literasi sains siswa. Sehingga dapat dilihat bahwa nilai dari hasil angket siswa terhadap sains lebih tinggi kelas eksperimen dibandingkan kelas kontrol.

Hasil penelitian ini sejalan dengan hasil penelitian (Ahmadi et al., 2016) yang mengangkat tentang Green Chemistry pada materi asam basa, bahwa modul CTL berorientasi Green Chemistry dapat digunakan untuk menunjang kegiatan belajar di dalam kelas dan siswa dapat diberikan kesempatan untuk berlatih mengembangkan keterampilan berpikir, bersikap ilmiah serta dapat membuat suatu hubungan antara pengetahuan yang dimiliki dengan penerapannya dalam kehidupan sehari-hari dengan membaca sehingga dapat menumbuhkan literasi sains siswa.

Hasil penelitian ini juga relevan dengan penelitian yang dilakukan oleh (Kimianti et al., 2016) bahwa efektifitas modul Learning Cycle $5 E$ berorietasi green chemistry dalam meningkatkan literasi sains siswa tinggi dengan nilai $\mathrm{N}$-gain rata-rata yang diperoleh adalah sebesar 0,8. Diungkapkan juga bahwa Modul Learning Cycle $5 E$ berorietasi green chemistry memiliki karakteristik tersendiri jika dibandingkan dengan bahan ajar pada umumnya. Item-item yang terdapat dalam modul tersebut memiliki keterkaiatan yang sangat erat dengan kehidupan sehari-hari (kontekstual) siswa dan relevan dengan isu-isu global yang terjadi sehingga melatih siswa untuk melakukan suatu penyelesaian ilmiah secara prosedural dan sistematik melalui kerja individu maupun kelompok serta dapat menuntun siswa untuk dapat menyelesaikan masalah khususnya pada lingkungan.

\section{KESIMPULAN}

Terdapat pengaruh yang signifikan modul PBL berorientasi green chemistry pada materi hidrolisis garam terhadap literasi sains siswa dalam aspek kompetensi. Hal ini dibuktikan : hasil 
uji signifikansi (uji t-test polled varians) yaitu thitung $>$ ttabel, yaitu 2,052>1,99 dari taraf sigifikansi 0.05 . Nilai rata-rata literasi sains siswa kelas eksperimen lebih tinggi dibandingkan nilai rata-rata kelas kontrol $(\mathrm{x}>\mathrm{y}=77,28>72,75)$

\section{REKOMENDASI}

Perlu pembiasaan diterapkan pembelajaran dengan modul PBL berorientasi green chemistry agar semua langkah-langkah pembelajaran terlaksana. Pada instrumen, sebaiknya soal-soal perlu disesuaikan dengan materi agar tidak terjadi miskonsepsi pada materi yang diajarkan. Peneliti selanjutnya bisa menggunakan di atas 6 prinsip green chemistry dari 12 prinsip green chemistry yang disesuaikan dengan materi pada modul atau LKS selanjutnya.

\section{DAFTAR PUSTAKA}

Ahmadi, H. P., Suryati, S., \& Khery, Y. (2016). Pengembangan Modul Contextual Teaching And Learning (CTL) Berorientasi Green Chemistry untuk Pertumbuhan Literasi Sains Siswa. Hydrogen: Jurnal Kependidikan Kimia, 4(1), 17-25.

Andrew, P. and Andrei, H. 2014. Green Chemistry Metrics A Guide to Determining and Evaluating Process Greeness. Springer Cham Heidelberg: New York, Dordrecht London.

Chandrasegaran, A.L, Treagust, D.F \& Mocerino, M. (2007). The development of A TwoTier Multiple-choice Diagnostic Instrument For Evaluating Secondary School Students' Ability To Describe And ExplainReactions Using Multiple Levels of representation. Chemistry education Research and Practice, Vol. 8(3), 293-307.

Fauziah, N., Suryati, S., \& Mashami, R. A. (2016). Pengembangan Modul Problem Based Learning (PBL) Berorientasi Green Chemistry untuk Peningkatan Literasi Sains Siswa. Hydrogen: Jurnal Kependidikan Kimia, 4(2), 94-102.

Isrotun, U. (2014). Peningkatan Pemahaman Konsep Matematika Melalui Penerapan Pembelajaran Realistik (PTK Pada Siswa Kelas VIIIH Semester Genap MTs Negeri Surakarta II Tahun Ajaran 2013/2014) (Doctoral dissertation, Universitas Muhammadiyah Surakarta).

OECD.2013. Education at a Glance 2013 : OECD Indicators, OECD Publishing. http://dx.doi.org/10.1787/eag-2013-en (diakses 24 November 2017)

PISA. 2015. Draft Science Framework PISA 2015 : www.oecd.org (diakses 24 November 2017).

Rosita, A., \& Marwoto, P. (2014). Perangkat Pembelajaran Problem Based Learning Berorientasi Green Chemistry Materi Hidrolisis Garam untuk Mengembangkan Soft Skill Konservasi Siswa. Jurnal Pendidikan IPA Indonesia, 3(2).

Rosy, B., \& Pahlevi, T. (2015). Penerapan problem based learning untuk meningkatkan kemampuan berpikir kritis dan keterampilan memecahkan masalah. In Prosiding Seminar Nasional (Vol. 160).

Kimianti, F., Suryati, S., \& Dewi, C. A. (2016). Pengembangan Modul Learning Cycle 5e Berorientasi Green Chemistry pada Materi Sistem Koloid Untuk Peningkatkan LiterasI Sains Siswa. Hydrogen: Jumal Kependidikan Kimia, 4(2), 70-79.

Nurbaity, N. (2011). Pendekatan Green Chemistry Suatu Inovasi Dalam Pembelajaran Kimia Berwawasan Lingkungan. Jurnal Riset Pendidikan Kimia (JRPK), 1(1), 13-21.

Setyosari, H. P. (2016). Metode penelitian pendidikan \& pengembangan. Prenada Media.

Suryati, S., Khery, Y., \& Dewi, C. A. (2017). Development Strategy of Inquiry Based Mobile Learning on General Chemistry Classroom. 
Suryati, S., Khery, Y., Nufida, B. A., \& Rahayu, S. (2020). Identifikasi Kompetensi Literasi Sains Calon Guru Kimia. Jurnal Zarah, 8(1), 50-55.

Yuliani, Y., Cahyani, D., \& Roviati, E. (2016). Penerapan Pembelajaran IPA Berbasis Keterampilan Proses Sains untuk Meningkatkan Literasi Sains pada Mata Pelajaran IPA di Kelas VII Materi Pokok Pencemaran Lingkungan di SMPN 1 Cikijing. Scientiae Educatia: Jurnal Pendidikan Sains, 5(2), 122-135.

Yustiqfar, M. Suryati, \& Mashami, R. A. 2017. Pengaruh Penggunaan Modul CTL Berorientasi Green Chemistry pada Materi Asam Basa terhadap Literasi Sains Siswa.

Yuliati, Y. (2017). Literasi sains dalam pembelajaran IPA. Jurnal cakrawala pendas, 3(2). 